\title{
POŠTA
}

TELEKOMUNIKÁCIE A

ELEKTRONICKY OBCHOD

\section{PROBLEMATIKA UNIVERZÁLNÍ POŠTOVNÍ SLUŽBY}

\author{
Libor Švadlenka, Jan Roth *
}

\section{Úvod}

V EU je v současnosti 27 členských států, mezi které od května roku 2004 patř́i i ČR. Ve všech státech EU funguje poštovní trh, který se řídí právními předpisy ES a potažmo národními předpisy jednotlivých členských zemí. Uzpůsobit národní poštovní sektory podmínkám poštovního trhu EU však musí i další evropské státy, které hodlají přistoupit k EU.

V sektoru poštovních služeb jednotlivých členských států EU působí mnoho poštovních operátorů, univerzální poštovní službu však poskytuje v každé zemi pouze jeden z nich. Proces postupné liberalizace poštovního trhu EU má vliv na provozování univerzální služby v budoucnosti. Úplným zrušením tzv. poštovních monopolů, tj. vyhrazených oblastí, v jejichž rámci mohou národní poštovní operátoři výhradně poskytovat určité služby jako jakousi kompenzaci za svoji povinnost poskytovat nákladově náročnou univerzální poštovní službu, se mohou národní poštovní operátoři v některých členských státech dostat do finančních potíží, čímž by se také ohrozilo poskytování univerzální poštovní služby. Tato situace může nastat zejména $\mathrm{v}$ těch zemích, které nejsou na liberalizaci poštovního trhu připraveny a u kterých je malý počet zasílaných poštovních zásilek na jednoho obyvatele. Obě tyto podmínky bohužel splňuje ČR, která se dokonce podle studie poradenské firmy PricewaterhouseCoopers z roku 2006 umístila na předposledním místě v připravenosti na plné otevření poštovního trhu hned za posledním Rumunskem.

Za účelem zajištění poskytování univerzální poštovní služby tak bude nutné nalézt alternativní způsob kompenzace pro její poskytovatele.

Cílem tohoto článku je analýza poštovních právních předpisů EU a ČR, vysvětlení pojmů univerzální poštovní služba, poskytovatel univerzální poštovní služby a jejich prezentace v kontextu EU a ČR.

\section{Právní rámec sektoru poštovních služeb}

Pro správné pochopení poštovního trhu je třeba nejprve určit a vysvětlit relevantní právní předpisy. Ty totiž určují podmínky a společná pravidla pro rozvoj poštovního trhu v rámci EU i jednotlivých zemí.

\footnotetext{
* Ing. Libor Švadlenka, Ph.D., Univerzita Pardubice, Dopravní fakulta Jana Pernera, Katedra dopravního managementu, marketingu a logistiky, Studentská 95, 53210 Pardubice, Tel.: 466036375, E-mail: Libor.Svadlenka@upce.cz

* Ing. Jan Roth, Česká pošta, s.p., Sekce řízení poštovní přepravy, Politických Vězňo 909/4, 11500 Praha 1, Tel.: 221132 467, E-mail: Roth.Jan@cpost.cz.
} 


\section{Právní předpisy platné pro oblast poštovních služeb EU}

V rámci EU jsou nejdůležitějšími právními předpisy upravujícími sektor poštovních služeb následující Směrnice a vyhlášky:

- Směrnice 97/67/EC Evropského parlamentu a Rady o společných pravidlech pro rozvoj vnitřního trhu poštovních služeb Společenství a zvyšování kvality služby,

- Vyhláška č. 98/EC 39/02 Evropské komise o uplatňování pravidel konkurence na poštovní sektor a o hodnocení některých státních opatření vztahujících se k poštovním službám,

- Směrnice 2002/39/EC Evropského parlamentu a Rady pozměňující Směrnici 97/67/EC, pokud jde o další otevírání poštovních služeb Společenství konkurenci.

Právě v této době probíhá na úrovni EU, resp. na úrovni jednotlivých členských států EU diskuse o novele Směrnice 97/67/EC, jejíž současné znění je platné pouze do 31.12.2008. V této, pro poštovní sektor zásadní, směrnici jsou stanoveny:

- $\quad$ společná pravidla pro poskytování univerzální poštovní služby v ES,

- $\quad$ kritéria pro stanovení služeb, které mohou být vyhrazeny poskytovatelům univerzální poštovní služby a podmínky, kterými se řídí poskytování nevyhrazených služeb,

- $\quad$ tarifní principy a průhlednosti účtů pro poskytování univerzální poštovní služby,

- principy harmonizace technických norem,

- $\quad$ pravidla týkající se vytvoření nezávislých národních regulačních úřadů.

Povinností členských států EU je transponovat ustanovení daná těmito směrnicemi do svých předmětných národních právních předpisů. Ustanovení vyhlášek Evropské komise sice není závazné pro jednotlivé členské státy, nicméně i zde je vyvíjen ze strany Evropské komise silný tlak na jejich respektování.

\section{Právní předpisy platné pro oblast poštovních služeb ČR}

V rámci ČR jsou nejdůležitějšími dokumenty upravující poštovní služby následující právní předpisy:

- Zákon č. 29/2000 Sb., o poštovních službách, ve znění pozdějších předpisů,

- Nařízení vlády č. 100/2005 Sb., kterým se mění nařízení vlády č. 140/2000 Sb., kterým se stanoví seznam oborů živností volných, ve znění pozdějších předpisů, a nařízení vlády č. 469/2000 Sb., kterým se stanoví obsahové náplně jednotlivých živností, ve znění pozdějších předpisů,

- $\quad$ Nařízení vlády č. 512/2005 Sb., o stanovení rozsahu poštovního oprávnění.

Naprosto zásadní je pro sektor poštovních služeb ČR výše uvedený zákon č. 141/2005 Sb., který upravuje:

- $\quad$ podmínky pro poskytování a provozování poštovních služeb v ČR,

- $\quad$ práva a povinnosti vznikající při poskytování a provozování poštovních služeb v ČR,

- zvláštní práva a zvláštní povinnosti provozovatelů poštovních služeb povinných zajišt'ovat základní služby.

\section{Univerzální poštovní služba a její poskytovatelé}

Všechny členské státy EU mají samozřejmě zájem na tom, aby byla na jejich území poskytována univerzální poštovní služba, nebot' poštovní služby jsou obecně chápány jako služby sociálního charakteru, které mají být př́stupné všem obyvatelům bez jakékoli diskriminace. 


\section{Univerzální poštovní služba v evropském kontextu}

Výše uvedené potvrzuje bod 1 článku 3 Směrnice 97/67/ES, který stanoví povinnost členským státům zajistit pro své uživatele poštovních služeb právo na univerzální službu zahrnující trvalé poskytování poštovní služby ve stanovené kvalitě ve všech místech na jejich území za dostupné ceny pro všechny uživatele. $Z$ dalších bodů článku 3 této směrnice vyplývá pro poskytovatele univerzální poštovní služby povinnost zajistit tuto univerzální poštovní službu během všech pracovních dní a nejméně pětkrát týdně, kromě okolností nebo geografických podmínek považovaných národním regulačním orgánem za mimořádné, a to minimálně jedním sběrem a jedním dodáním. Univerzální poštovní služba musí obsahovat minimálně tyto služby:

- $\quad$ sběr, třídění, přepravu a dodání poštovních zásilek do $2 \mathrm{~kg}$,

- $\quad$ sběr, trrídění, přepravu a dodání poštovních balíků do $10 \mathrm{~kg}$ (národní regulační autority mohou v jednotlivých členských státech zvýšit limit hmotnosti až na 20 kg),

- $\quad$ služby doporučených zásilek a zásilek s udanou cenou.

Další povinnosti týkající se poskytování univerzální poštovní služby v rámci EU vyplývají např́íklad z bodu 5 této směrnice, stanovující následující požadavky:

- $\quad$ nabízená služba musí zaručovat, že budou splněny základní potřeby,

- uživatelům musí být nabízena stejná služby za srovnatelných podmínek,

- $\quad$ služba se stane dostupnou bez jakékoli diskriminace ve kterékoli podobě, zvláště bez diskriminace vzniklé z politických, náboženských nebo ideologických důvodů,

- $\quad$ služba nebude přerušena nebo zastavena s výjimkou případů vyšší moci,

- $\quad$ služba se bude rozvíjet $\mathrm{v}$ závislosti na technickém, hospodářském a společenském prostředí a na potřebách uživatelů.

\section{Univerzální poštovní služba v českém kontextu}

Předmětný český právní předpis, tj. zákon č. 29/2000 Sb., ve znění pozdějších předpisů nehovoří o univerzální poštovní službě, ale o tzv. základní poštovní službě, což podle $§ 2$ písm. j) tohoto zákona chápe jako poštovní služby a zahraniční poštovní služby, které jsou vzhledem $\mathrm{k}$ potřebám veřejnosti pod ochranou státu zajišt'ovanou způsobem podle tohoto zákona. § 19 tohoto zákona stanoví povinnost zajistit všeobecnou dostupnost těchto služeb na celém území ČR, s tím, že národní regulační autorita (NRA), kterou je v ČR Český telekomunikační úřad (ČTÚ) v poštovním věstníku č. 3 z roku 2005 stanovil, které konkrétní služby jsou vzhledem k potřebám veřejnosti službami základními. Jedná se o těchto 16 poštovních služeb a zahraničních služeb:

- Obyčejná služba (vnitrostátní)

- Obyčejná služba pro nevidomé (vnitrostátní)

- Doporučená služba (vnitrostátní)

- Doporučená služba pro nevidomé (vnitrostátní)

- Balíková služba (vnitrostátní)

- Poštovní poukaz hotovost - hotovost (vnitrostátní)

- Poštovní poukaz účet - hotovost (vnitrostátní)

- Poštovní poukaz hotovost - účet (vnitrostátní)

- Obyčejná služba (do zahraničí)

- Obyčejná služba - tiskoviny (do zahraničí)

- Obyčejná služba pro nevidomé (do zahraničí)

- Doporučená služba (do zahraničí)

- Doporučená služba - tiskoviny (do zahraničí)

- Doporučená služba pro nevidomé (do zahraničí) 
- Balíková služba (do zahraničí)

- Poštovní poukaz hotovost - hotovost (do zahraničí)

Pojmy základní poštovní služba a univerzální poštovní služba vyjadřují tedy stejnou věc, nicméně obsahově se přeci jen trochu liší. Základní služba v sobě obsahuje i poštovní poukazy, což univerzální poštovní služba vůbec nezahrnuje.

\section{Poskytovatelé univerzální poštovní služby v EU}

Poskytovatelem univerzální služby je veřejný nebo soukromý subjekt poskytující univerzální poštovní službu nebo její část uvnitř členského státu EU. Jeho totožnost musí být oznámena Komisi EU v souladu s článkem 4 Směrnice 97/67/ES. Každý členský stát stanoví v souladu s právem Evropského společenství povinnosti a práva přidělená poskytovateli univerzální služby a zveřejní je.

Poskytovatelé univerzální služby v jednotlivých členských zemích EU jsou uvedeni v Tab. 1. Někteří z těchto operátorů mají právní status státní organizace, převažují však organizace soukromé (akciové společnosti či společnosti s ručením omezeným). Pro českou poštu, s.p., která je doposud státní podnikem byl vládou stanoven termín transformovat ji na akciovou společnost, v první fázi sto procentně vlastněnou státem, do poloviny roku 2009.

Tab. 1 - Seznam poskytovatelů univerzální poštovní služby v rámci členských států EU

\begin{tabular}{|l|l|}
\hline \multicolumn{1}{|c|}{ členské země EU } & \multicolumn{1}{c|}{ poskytovatelé univerzální služby (USP) } \\
\hline \hline Belgie & La Poste \\
\hline Bulharsko & Bulgarian Posts \\
\hline Česká republika & Česká pošta \\
\hline Dánsko & Post Danmark \\
\hline Estonsko & Eesti Post \\
\hline Finsko & Posti \\
\hline Francie & La Poste \\
\hline Irsko & An Post \\
\hline Itálie & Poste Italiane \\
\hline Kypr & Cyprus Post \\
\hline Litva & Lietuvos Paegas \\
\hline Lotyšsko & Latvijas Pasts \\
\hline Lucembursko & P \& T Luxembourg \\
\hline Mad'arsko & Magyar Posta \\
\hline Malta & Maltapost \\
\hline Německo & Deutsche Post \\
\hline Nizozemsko & TNT \\
\hline Polsko & Poczta POLSKA \\
\hline Portugalsko & CTT \\
\hline Rakousko & Österreichische Post \\
\hline Rumunsko & Posta Romana \\
\hline Recko & ELTA Hellenic Post \\
\hline Slovensko & Slovenská pošta \\
\hline Slovinsko & Posta Slovenije \\
\hline Spojené království & Royal Mail \\
\hline Španělsko & Correos \\
\hline Švédsko & Posten \\
\hline & \\
\hline
\end{tabular}

Zdroj: CAMPBELL, J. I. et al. Main developments in the European postal sector (2004 - 2006) - Annexes. WikConsult [online]. 2006 [cit. 2007-11-22]. Dostupný z WWW: <http://ec.europa.eu/internal_market/post/doc/ studies/2006-wik-final-appendices_en.pdf> 


\section{Závěr}

Pro poskytovatele univerzální služby a univerzální poštovní službu jako takovou bude v nejbližší době klíčové konečné znění novely základní Směrnice 97/67/EC, které je právě v současné době na úrovni vlád jednotlivých členských států projednáváno. Dá se předpokládat, že univerzální poštovní služba bude i nadále chápána jako služba sociální, která musí být lidem dostupná, alespoň v určité minimální úrovni. $Z$ dosud prezentovaných návrhů této směrnice je také zřejmé, že klíčový problém spojený s univerzální poštovní službou, tj. zajištění jejího financování, tato směrnice taktně obejde a pouze naznačí možné postupy jejího financování (včetně již mnohokrát prezentované možnosti prostřednictvím kompenzačního fondu apod.) s tím, že hlavní rozhodovací břímě ponesou jednotlivé členské státy. Ty tedy v konečném důsledku rozhodnou o poskytování univerzální poštovní služby v podmínkách plně liberalizovaného trhu, kdy stávajícím poskytovatelům univerzální služby odpadne významný zdroj financování nákladově náročné univerzální poštovní služby. Jak již bylo v úvodu tohoto článku řečeno, výpadek těchto př́ímů bude rozhodně více citelný u poštovních operátorů ze zemí s nízkým počtem posílaných poštovních zásilek na jednoho obyvatele, stejně jako zemím dosud málo připraveným na plnou liberalizaci poštovního trhu (včetně ČR). Zejména v těchto zemích pak zřejmě bude velmi živě diskutována možnost omezit rozsah stávající univerzální služby, stejně jako různé způsoby jejího financování. V podmínkách ČR se dá předpokládat pravděpodobné řešení problematiky liberalizace poštovního trhu versus poskytování univerzální poštovní služby v takové podobě, kdy podmínkou poskytování lukrativních, v současné době vyhrazených poštovních služeb, bude jejich poskytování na univerzální bázi. Žádné kompenzační fondy, ani státní dotace tedy zřejmě aplikovány nebudou. Pokud jde o kompenzační fond, je to rozhodnutí zcela logické, vzhledem k prakticky žádným zkušenostem s jeho aplikací (nepočítáme-li Itálii, kde sice funguje, ale prŕijmy naprosto nekryjí potřeby zajištění univerzální poštovní služby) a složitostí jeho spravování. Pokud jde o státní dotace, i zde je rozhodnutí zcela logické, nebot' tyto dotace by šly proti základnímu principu, aplikovanému již od 90-tých let minulého století, totiž principu samofinancovatelnosti poštovního operátora, nehledě na potenciální problémy s kř́ízovým financováním apod.

\section{Literatura}

[1] HOLEMÝ, Jan a kolektiv. Strukturální analýza a prognóza vývoje českého poštovního sektoru v kontextu s relevantními trendy Společenství. č. úkolu: 1-740-1050 - Etapa 1 (1. část). Praha, leden 2006. 68 s.

[2] Funding universal service obligations in the postal sector. Oxera [online]. 2007 [cit. 2007-11-22]. Dostupný z WWW: <http://www.oxera.com/cmsDocuments/Funding $\%$ 20universal\%20services\%20obligations\%20in\%20the\%20postal\%20sector.pdf $>$.

[3] CAMPBELL, J. I. et al. Main developments in the European postal sector (2004 - 2006) - Final Report. Wik-Consult [online]. 2006 [cit. 2007-11-22]. Dostupný z WWW: < http://ec.europa.eu/internal_market/post/doc/studies/2006-wik-final_en.pdf>.

[4] KUYPERS, B. et al. The impact on Universal service of the full market accomplishment of the postal internal market in 2009 - Final Report. PricewaterhouseCoopers [online]. 2006 [cit. 2007-11-22]. Dostupný z WWW: <http://ec.europa.eu/internal_market/ post/doc/studies/2006-impact-report_en.pdf>.

[5] Zákon č. 29/2000 Sb. o poštovních službách a o změně některých zákonů ve znění zákona č. 517/2002 Sb., zákona č. 225/2003 Sb., zákona č. 95/2005 Sb., zákona č. 501/2004 Sb., 
zákona č. 413/2005 Sb., zákona č. 444/2005 Sb., zákona č. 264/2006 Sb. a zákona č. $110 / 2007 \mathrm{Sb}$.

[6] SMĚRNICE 97/67/ES o společných pravidlech pro rozvoj vnitřního trhu poštovních služeb Společenství a zvyšování kvality služby.

[7] ČOREJOVÁ, T., MADLEŇÁKOVÁ, L. K niektorým otázkam vývoja na poštových trhoch. In: Sbornik př́spěvkỉ z mezinárodni vědecké konference "Podniky v podmínkách procesu globalizace a integrace", 2004. s. 19-23.

[8] PRŮ ̌SA, P., ŠVADLENKA, L. Estimation of the profit impact on the incumbent postal operators for different scenarios of liberalisation. Scientific Papers of the University of Pardubice,Series B - The Jan Perner Tranport Faculty, 2004.

[9] MADLEŇÁK, R., MADLEŇÁKOVÁ, L. The postal market analysis in Europe, In: Studies of Faculty of operation and economics of transport and communications of University of Žilina. s. 117-122. 